\title{
Emzirme Döneminde Olan Annelerin Bebek Besleme Alışkanlıkları ve Etkileyen Faktörler
}

\author{
Infant Feeding Practices of Breast-Feeding Mothers and Affecting Factors
}

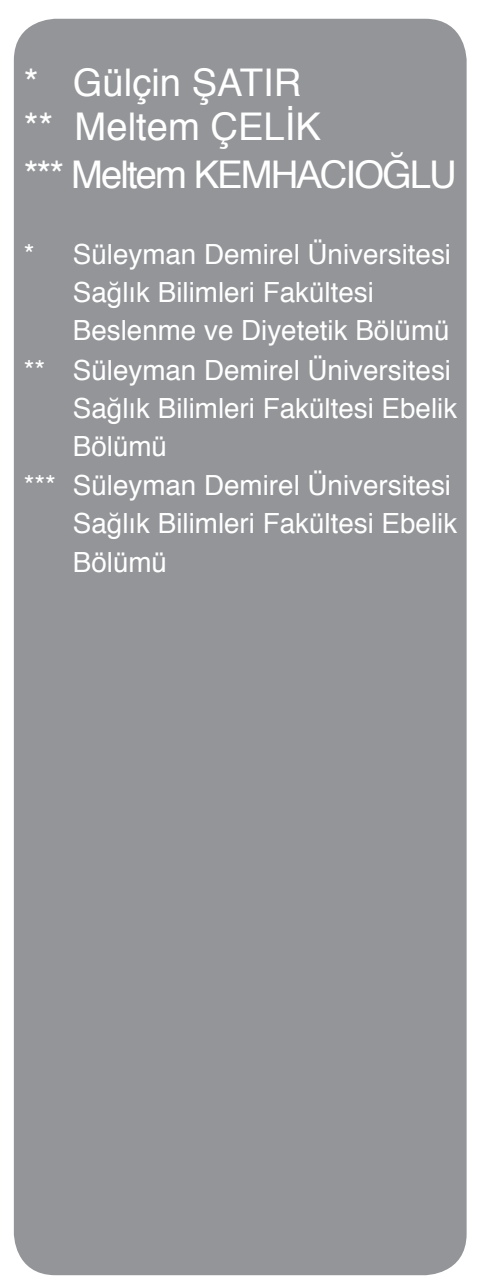

Yazışma Adresi:

Süleyman Demirel Üniversitesi Sağlık Bilimleri Fakültesi Beslenme ve Diyetetik Bölümü, Isparta. Tel: 0 2462111163 Fax:0 2462111794 e-mail: gulcinsatir@sdu.edu.tr

\section{Öz}

Amaç: 0-12 ay bebek beslenmesi, büyüme, gelişme ve hastalıklardan korunmada önemli rol oynamaktadır. Bu çalışma; 0-12 ay arasında çocuğu olan annelerin anne sütü, mama ve ek gıda ile bebek besleme konusunda bilgi, tutum ve davranışlarının saptanması amacıyla gerçekleştirilmiştir. Gereç ve Yöntem: Çalışma; kesitsel ve tanımlayıcı tiptedir. Araştırma evreni, 12 aylıktan küçük, sağlıklı ve emme yeteneğine sahip çocuğu olan, emzirme ile ilgili herhangi bir tıbbi kısıtlaması olmayan toplam 5 ASM'den seçilmiş 100 anneden oluşmaktadır. Katılımcılara 2 bölüm ve 43 sorudan oluşan anket formu yüz yüze görüşülerek uygulanmıştır. Verilerin değerlendirilmesinde ki-kare testi kullanılmıştır. Bulgular: Doğumdan hemen sonra annelerin \%87'sinin ilk olarak anne sütü verdiği, diğerlerinin anne sütü dışındaki sıvılar verdiği tespit edilmiştir. Annelerin \%61'i yaz aylarında doğan bebeklere su verilmesi gerektiğini belirtmiştir. Gelir durumu kötü olan annelerin \%53.8'i ancak 10-12. aylarda ek gıdaya başlarken, gelir düzeyi iyi olan annelerin \%88,9'u 4-6. aylarda ek gıdaya başlamıştır. Eğitim düzeyi düşük olan annelerin çoğunluğu $(\% 48,8)$ daha çok aile büyüklerinin veya çevresinin etkisiyle ek gıdaya başladığını belirtirken, eğitim düzeyi yüksek olan kadınlarda çoğunluk (\%40), sağlık personeli ve kendi isteğiyle bu kararı almaktadırlar. Bebeklerin ilk üç aylık döneminde herhangi bir ek gıda verilmediği görülürken, 3. ay sonrasında yoğurt benzeri ürünler ve 6 . aydan sonra özellikle meyve püreleri en çok tercih edilen ek gıdalardır. Sonuç: Annelerin eğitim düzeyi ve çalışma durumunun bebeğin ek gıdaya başlama süresini etkilediği saptanmıştır. Annelerin anne sütü ve emzirme döneminde beslenme uygulamaları konusunda bilgileri orta düzeydedir. Anne sütü ve emzirme konusundaki eğitimin gebelik sürecinde verilmesi önerilmektedir.

Anahtar Kelimeler: Anne sütü, Beslenme davranışı, Emzirme 
that they had begun to give additional food with an advice from family elders or the environment, while the majority of women with high education level (40\%), make this decision voluntarily or by health professionals. While during the first three months of the baby is not given any additional food products, after the $6^{\text {th }}$ month especially yogurt-like food and after 3 months fruit purees are most preferred supplementary food. Conclusion: Mothers' educational level and working conditions has been found to affect the time to start supplementary food for babies. We have found that the knowledge about breastfeeding and feeding practices of mothers are moderate. It is recommended to give education on mother's milk and breastfeeding during pregnancy.

Keywords: Human milk; Feeding Behavior; Breastfeeding

\section{Giriş}

Sağığın temellerinin atıldığı ilk yıllarda beslenme; büyüme ve gelişme açısından çok önemlidir. Özellikle ilk 24 aya kadar devam eden süreç; çocuklarda en uygun büyümegelişme ve yaşama sağlıklı başlangıç için ilk adımdır. Bebeğin yanlış, yetersiz ya da fazla beslenmesi, bebek ölümlerine neden olabilmekte, hatta ileri yaşam sağlığı üzerine olumsuz etki göstermektedir. 24 aydan küçük çocuklarda yetersiz beslenmenin erken dönem sonuçları; hastalanma ve ölüm oranında artış, büyüme ve zekâ gelişimindeki gecikmedir. Günümüzde çocukluk çağı ve özellikle ilk 24 ay beslenmesinin ileri yaşam sağlığ üzerine etkileri nedeniyle, süt çocuğu ve küçük çocuklarda sağlıklı beslenme konusunda anne adaylarının, annelerin bilinçlendirilmesi bir toplum sağlığı hizmetidir. Çünkü anne sütü, besin öğelerini her bebeğin gereksinimine göre uygun miktarlarda ve biyolojik yararlılığı yüksek nitelikte içeren optimum besin kaynağıdır.

Bebek beslenmesi ile ilgili uygulamaların tarihsel olarak gelişimi incelendiğinde en önemli besinin anne sütü olduğu görülmektedir. Dünya Sağlık Örgütü (WHO); bebeklerin ilk 6 ayda düzenli kilo aldıkları takdirde sadece anne sütü ile beslenmelerini önermektedir (1). Yine WHO ve UNICEF 'inde önerdiği gibi ilk 6 ay yalnızca anne sütü, 6 aydan sonra uygun ek besinlerle birlikte 2 yaşına kadar anne sütü ile beslenilmeye devam edilmelidir $(2,3)$. UNICEF ve WHO sadece anne sütüyle beslenme oranlarını 0-6 aylık bebekler için \%35, 4 ayın altındakiler için ise \%39 olarak bildirmektedir (1).

Emzirme; Ülkemizde yaygın bir uygulamadır ve Türkiye Nüfus Sağlık Araştırması (TNSA) 2013 verilerine göre tüm çocukların \%97'si bir süre emzirilmiştir. Ancak emzirme zamanı ile ilgili bilgilere bakıldığında Ülkemizde anne sütü ile beslenmeye başlamanın oldukça geç olduğunu da göstermektedir. Çocuklarda sadece anne sütü ile beslenme TNSA 2008'de \%42 iken, TNSA 2013'te \%30'a düşmüştür; dolayısıyla sadece anne sütüyle beslenme önerildiği şekilde yaygın olarak uygulanmamaktadır (4).

0-12 ay çocukların yeterli ve dengeli beslenmesinde annelerin bebek beslenmesi konusunda eğitim düzeyi önemli bir etkendir. Buna bağlı olarak anne adayının doğum öncesi ve doğum sonrası anne sütü, emzirme ve ek gıdalar konusunda daha fazla bilgilendirilmesi ve bilinçlendirilmesi gerekmektedir. Bir bebeğin sağlıklı beslenmesinde bebeğin bakımını üstlenen kişilerin bu konuda yeterli bilgi ve donanıma sahip olmaları büyük önem taşımaktadır. TNSA 2013 verilerine göre $0-1$ ay sadece anne sütü alma oranı $\% 57.9$ iken, 4-5. aylarda bu oran \%9.5'lara düşmektedir. UNICEF'in 2008 yılı verilerine göre gelişmekte olan ülkelerde 6 ayın altında sadece anne sütü verme oranlarının \%38 olduğu görülmektedir (3).

Ülkemizde daha önceden yapılmış pekçok çalışma, annelerin çoğunluğunun bebek beslenmesi konusunda eksik veya yanlış bilgiye sahip olduklarını göstermektedir (5, $6,9,10,11,12,13,14,15,16,17)$. Beslenme konusundaki bu yetersiz ve yanlış bilgiler bebeklerde büyüme ve gelişme geriliğine, çoğu önlenebilir olan hastalıkların daha sık görülmesine, sakatlıklara ve hatta ölümlere neden olabilmektedir. Ayrıca, anne ve bebeğin beslenmesi konusundaki bilgi düzeyi ve davranışlar, çeşitli algı ve inanışlardan etkilenerek şekillenmektedir. Bu araştırma; 0-12 ay arasında çocuğu olan annelerin anne sütü, formül mama ve ek gıda ile bebek besleme konusunda bilgi, tutum ve davranışlarının saptanması amacıyla gerçekleştirilmiştir.

\section{Gereç ve Yöntem}

Kesitsel tipteki bu çalışma, Kasım 2014 - Ocak 2015 tarihleri arasında Isparta II Merkezindeki 5 farklı Aile Sağlığı Merkezi (ASM)'nde yürütülmüştür. 0-12 ay emziren annelerin sosyo ekonomik seviyelerinin farklı olduğu Aile Sağlığı Merkezleri (ASM) tespit edilmiş ve 5 farklı ASM, araştırmanın kapsamına dahil edilmiştir. Bu ASM'ler örneklem grubu olarak seçilmiş ve böylece eğitim, yaş, ekonomik düzeyleri farklı olan annelerin emzirme ve tamamlayıcı gıdalarla ilgili farklı uygulamaları varsa onlara rastlama olasılığını artırılmaya çalışıımıştır. Araștırmacılar tarafından; Türkiye'de ki bebek beslenmesi ile ilgili çalışmalar incelenerek açık uçlu sorulardan oluşan anket formu hazırlanmıştır $(6,9,10,12,16)$. Anketin birinci bölümünde demografik, sosyal ve eğitim ile ilgili soruların, 
ikinci bölümünde bebek beslenmesi konularında soruların (bebeği emzirme süresi, emzirme sıklığı, emzirmeye ne zaman başladığı, emzirme için geçerli nedenler, emzirmenin bağışıklığa etkisi, anne sütünün bebeğe yeterli olup olmadığı, ek gıda beslenmesine kaçıncı ayda başladığı, ek gıda ile birlikte anne sütünün devamlılığı, ek gıdaların miktarı, lohusanın emzirme dönemindeki diyetin uygunluğu vb.) olduğu toplam 43 soru yer almıştır. Emziren, gönüllü ve iletişim kurabilen 100 anneye ulaşılmış ve araştırma ekibi tarafından yüz yüze görüşme tekniği ile uygulanmıştır. Araştırma esnasında annelere, proje konusunda sözel olarak bilgilendirilip sonrasında yazılı onamları alındıktan sonra anket formu uygulanmıştır. Görüşmeler, ilgili ASM'nin bir odasında gerçekleştirilmiş ve ortalama 20-25 dk sürmüştür. Anket sorularının yüz yüze görüşmelerle tamamlanması 3 aylık bir zaman diliminde gerçekleşmiştir. Ayrıca her değerlendirme sonrasında anneye yanlış cevaplandırdığı soruların doğru cevapları verilmiş ve ilgili konularda detaylı bilgi paylaşılmıştır.

Araştırmadan elde edilen veriler SPSS 17.0 (Statistical Package For Social Sciences) programı ile değerlendirilmiştir. Anket formundan elde edilen puanlar annelerin yaş, eğitim durumu, meslek, çocuk sayısına göre bazı sosyo demografik özellikleri ile karşılaştırılmıştır. İstatistiksel değerlendirmede ortalama puan kullanılmıştır. Bulgular; yüzdelik, ortalama, ki-kare, tek yönlü varyans analizi (ANOVA) ile analiz edilmiştir. Araştırmada anlamlılık düzeyi $p<0.05$ olarak alınmıştır.

\section{Etik Kurul Onayı}

$\mathrm{Bu}$ çalışmanın yürütülebilmesi için Süleyman Demirel Üniversitesi Tıp Fakültesi Klinik Araştırmalar Etik Kurulu Başkanlığından Etik Kurul Onayı (05.09.2014 ve 72867572050/2976 sayılı) alınmıştır. Ayrıca İ Sağlık Müdürlüğü izni (04.11.2014 tarih ve 98626970/100 sayılı) alınarak ASM'lerin tespitinde destek alınmıştır.

\section{Bulgular}

Araştırmada yer alan anne ve bebeklerine ait bazı özelliklerin dağılımı Tablo I'de sunulmuştur. Annelerin \%43'ü 21-25 yaş aralığında, \%29'u 26-30 yaş aralığında olduğundan genç anne oranı yüksektir. Eğitim durumlarına bakıldığında, $\% 57$ 'si lise ve üzeri mezunudur. Çalışan annelerin oranı \%21'dir. Çalışmamıza katılan annelerin en az 1 en çok 5 çocuğu olup ortalama çocuk sayısı 1,66'dır. Bunun yanı sıra annelerin \%80'i doğumunu devlet hastanesinde yaptığını belirtirken, \%20'si ise özel hastanede doğum yaptığını belirtmiştir. Doğumların \%79'u normal, \%21'i

Aablo 1 Anne ve bebeğe ait bazı karakteristik
özellikler $(n=100)$

\begin{tabular}{|c|c|}
\hline Özellik & Yüzde (\%) \\
\hline Anne & - - - - - - - \\
\hline \multicolumn{2}{|l|}{ Yaş } \\
\hline$\leq 20$ & 15,0 \\
\hline $21-25$ & 43,0 \\
\hline $26-30$ & 29,0 \\
\hline$>30$ & 13,0 \\
\hline \multicolumn{2}{|l|}{ Eğitim } \\
\hline$\leq$ İlkokul & 12,0 \\
\hline Ortaokul & 31,0 \\
\hline Lise ve üzeri & 57,0 \\
\hline \multicolumn{2}{|l|}{ Çalışma Durumu } \\
\hline Çalışmıyor & 79,0 \\
\hline Çalışıyor & 21,0 \\
\hline \multicolumn{2}{|l|}{ Gelir Düzeyi } \\
\hline Gelir giderden az & 13,0 \\
\hline Gelir gidere eşit & 78,0 \\
\hline Gelir giderden fazla & 9,0 \\
\hline \multicolumn{2}{|l|}{ Çocuk Sayısı } \\
\hline 1 & 60,0 \\
\hline 2 & 23,0 \\
\hline 3 ve üzeri & 17,0 \\
\hline \multicolumn{2}{|l|}{ Doğum Şekli } \\
\hline Normal & 79,0 \\
\hline Sezaryen & 21,0 \\
\hline \multicolumn{2}{|l|}{ Nerede Doğum Yaptığı } \\
\hline Devlet & 80,0 \\
\hline Özel & 20,0 \\
\hline \multicolumn{2}{|l|}{ Bebek } \\
\hline \multicolumn{2}{|l|}{ Yaş (ay) } \\
\hline $0-3$ & 47,0 \\
\hline $4-6$ & 15,0 \\
\hline $7-9$ & 9,0 \\
\hline 10-12 & 29,0 \\
\hline \multicolumn{2}{|l|}{ Cinsiyet } \\
\hline $\mathrm{K} I \mathrm{Z}$ & 54,0 \\
\hline Erkek & 46,0 \\
\hline
\end{tabular}

sezaryenle gerçekleşmiştir. Çalışmamıza katılan 0-12 ay emziren annelerin bebeklerin doğum ağırlıkları 2100-3900 $\mathrm{g}$ arasında olup ortalama $3070 \pm 1680 \mathrm{~g}$ ve yaşları ortalama $21,1 \pm 1,12$ haftalıktır. Bebeklerin \%54'ü kız ve \%46'sı erkektir. Anne sütü dışında ek gıdaya başlama ayı 4,6 $\pm 1,9$ ay, toplam anne sütü alma süresi 10,1 $\pm 3,1$ aydır. 
Tablo Il'de annelerin emzirmeyle ilgili sorulara verdikleri yanıtların eğitim durumuna göre karşılaştırmalı bilgisi sunulmuştur. Çalışmamıza katılan annelerin \%90'ı doğum öncesi dönemde anne sütü ve emzirmeyle ilgili eğitim aldığını belirtmiştir. Annelerin eğitim durumu ile emzirme konusunda eğitim alma arasında istatistiksel olarak anlamlı farklılık bulunmuştur $(p=0.000)$. Annelerin \%89'u anne sütü sağımı ve saklama koşullarıyla ilgili bilgisi olduğunu belirtmiştir. Doğumdan hemen sonra annelerin \%87'si ilk olarak anne sütü verdiğini ifade ederken, \%4'ü mama, \%1'i ise su verdiğini belirtmiştir. Ağız sütü (kolostrum) hakkında fikir sahibi olanların oranı \%86 olarak bulunmuştur. Ankete katılan annelerin \%79'u bebeğinin beslenmesiyle ilgili bir sorunla karşılaştığında önce sağlık çalışanlarından yardım aldığını, \%12'si aile büyüklerinden, \%9'u diğer kaynaklardan (internetten, yazılı-görsel medya v.b.) yardım aldığını belirtmiştir. Annelerin \%61'i yaz aylarında doğan bebeklere su verilmesi gerektiğini ifade etmişlerdir. Emzirmenin doğum kilolarının kaybına neden olacağını düşünenlerin oranı \%91 olarak saptanmıştır. Tablo II' deki verilen bu durumlar ile annelerin eğitim durumu arasında herhangi anlamlı bir farklılık bulunmamıştır. Ayrıca çalışan kadınların çoğunluğu (\%76.2) ilk 4-6 ayda ek gıdaya başlarken, ev hanımı annelerin \%46.8'i ek gıdaya başlamışlardır.

Tablo 2 Annelerin eğitim durumuna göre emzirme ve beslenme ile ilgili bazı sorulara verdikleri cevapların dağılımı

\begin{tabular}{|c|c|c|c|}
\hline \multirow[b]{2}{*}{ Özellikler } & \multicolumn{2}{|c|}{ Eğitim Durumu } & \multirow{2}{*}{$\begin{array}{c}\text { Toplam } \\
\text { n (\%) }\end{array}$} \\
\hline & $\begin{array}{c}\text { İlkokul-Ortaokul } \\
\text { n (\%) }\end{array}$ & $\begin{array}{l}\text { Lise ve üzeri } \\
\text { n (\%) }\end{array}$ & \\
\hline \multicolumn{4}{|c|}{ Doğum öncesi anne sütü ve emzirme ile ilgili bilgi aldı mı?* } \\
\hline Evet & $33(76,7)$ & $57(100,0)$ & $90(90,0)$ \\
\hline Hayır & $10(23,3)$ & - & $10(10,0)$ \\
\hline \multicolumn{4}{|c|}{ Anne sütü sağımı ve saklama koşulları ile ilgili bilgisi var mı? } \\
\hline Evet & $37(86,0)$ & $52(91,2)$ & $89(89,0)$ \\
\hline Hayır & $6(14,0)$ & $5(8,8)$ & $11(11,0)$ \\
\hline \multicolumn{4}{|c|}{ Doğumdan sonra bebek ilk ne ile beslendi? } \\
\hline $\mathrm{Su}$ & $1(2,3)$ & - & $1(1,0)$ \\
\hline Şekerli su & $4(9,3)$ & $4(7,0)$ & $8(8,0)$ \\
\hline Mama & $1(2,3)$ & $3(5,3)$ & $4(4,0)$ \\
\hline Anne sütü & $37(86,0)$ & $50(87,7)$ & $87(87,0)$ \\
\hline \multicolumn{4}{|c|}{ Ağız sütünü (kolostrum) daha önce duymuş mu? } \\
\hline Evet & $40(93,0)$ & $46(80,7)$ & $86(86,0)$ \\
\hline Hayır & $3(7,0)$ & $11(19,3)$ & $14(14,0)$ \\
\hline \multicolumn{4}{|c|}{ Bebek beslenmesi ile ilgili bir sorun ile karşılaşıldığında nerelerden yardım alınmış? } \\
\hline Sağlık kuruşlarından & $32(74,4)$ & $47(82,5)$ & $79(79,0)$ \\
\hline Aile büyüklerinden & $8(18,6)$ & $4(7,0)$ & $12(12,0)$ \\
\hline Diğer (internet, basın) & $3(7,0)$ & $6(10,5)$ & $9(9,0)$ \\
\hline \multicolumn{4}{|c|}{ Yaz aylarında doğan bebeklere su verilmesi gerekir mi? } \\
\hline Evet & $26(60,5)$ & $35(61,4)$ & $61(61,0)$ \\
\hline Hayır & $17(39,5)$ & $22(38,6)$ & $39(39,0)$ \\
\hline \multicolumn{4}{|c|}{ Emzirmenin doğum kilolarının kaybında etkisi var mı? } \\
\hline Evet & 93,0 & 89,5 & 91,0 \\
\hline Hayır & 7,0 & 10,5 & 9,0 \\
\hline
\end{tabular}


Çalışma durumu ile ek gıdaya başlama tarihi arasındaki ilişki anlamlıık sınırında bulunmuştur $(p=0,051)$.

Emzirmenin yanında ek olarak anneler tarafından bebeklere verilen besinlerin yaş grubuna göre karşılaştırılması yapılmıştır. Buna göre, ilk 3 aylık dönemde annelerin bebeklerine herhangi bir ek gıdayı neredeyse hiç vermedikleri ve anne sütüyle besledikleri görülmektedir. İkinci 3 aylık dönemde yaklaşık iki anneden biri yoğurt yedirirken, muhallebi ve ev yapımı meyve püreleri en çok tercih edilen besinlerdir. 7-9 aylık bebeklere, annelerin $\% 90$ 'ı süt ürünlerine ek olarak; meyve suyu, püresi ve sebze çorbaları yedirmeye başlamışlardır. Annelerin yarısından fazlasının yumurta ve beyaz peynir yedirdiği izlenmiştir. 10-12 ay bebeklere neredeyse tüm besin gruplarından yedirildiği, en az tercih edilenin ise $\% 10$ oranı ile bal olduğu görülmektedir.

Gelir durumu kötü olan annelerin çoğunluğu $(\% 53,8)$ ek gıdaya 10-12. aylarda başlarken, orta ve iyi gelir düzeyine sahip annelerin çoğunluğu (sırasıyla \%55,1 ve \%88,9) 4-6. aylarda ek gıdaya başlamışlardır. Gelir durumu ile ek gıdaya başlama tarihi arasındaki fark anlamlıdır $(p=0,000)$. Ayrıca, eğitim düzeyi düşük olan annelerin çoğunluğu $(\% 48,8)$ daha çok aile büyüklerinin veya çevresinin etkisiyle ek gıdaya başladığını belirtirken, eğitim düzeyi yüksek olan kadınlarda çoğunluk (\%40), sağlık personeli ve kendi isteğiyle bu kararı almaktadırlar $(p=0,001)$.

\section{Tartışma}

Çalışmamızla uyumlu olarak Akova ve arkadaşlarının yaptığı çalışmada doğumdan sonra ilk 1-2 saat içinde anne sütüne başlama sıklığının $\% 78,9$ olduğu belirlenmiştir (5). TNSA 2013 verilerine göre ise doğumdan sonra ilk 1 saatte emzirme oranı \%50'dir (4). Yapılan çalışmalarda annenin eğitim düzeyi arttıkça bebeklerini ilk bir saat içinde emzirme oranları da artmaktadır. Açık ve arkadaşlarının 1999 yılında yaptıkları çalışmada, doğumdan sonra bebeğe ilk olarak şekerli su verme oranı \%25,4 iken (6), araştırmamızda doğumdan sonra bebeğe ilk olarak şekerli su verme oranı $\% 8$ olarak tespit edilmiştir. Anne sütünün \%87'si sudur ve emzirmenin ilk evresinde gelen ağız sütü (kolostrum) dahil süt, su bakımından oldukça zengin bir içeriğe sahiptir. Bu nedenle, bebeğin gereksinimi olan tüm su, sütten karşılanmakta, çok sıcak havalarda bile bebek, su ve sulu içeceklere gerek duymamaktadır $(7,8)$. Ünsür ve arkadaşlarının yaptığı çalışmada annelerin, \%91,3'ünün ağız sütünü (kolostrum) daha önceden bildikleri tespit edilmişken, \%8,7'sinin ağız sütünü bilmedikleri tespit edilmiştir (9). Ağız sütünü daha önceden duyduğunu söyleyen annelerin \%65,6'sı ağız sütünün bebeğe verilmesi gerektiğini belirtirken, \%34,4'ünün bu konuda fikrinin olmadığı belirlenmiştir (9). Çalışmamızda ise ağız sütünü daha önceden duyduğunu ifade eden annelerin oranı
$\% 86$ 'dır. Kolostrum sütü önemli miktarda antikor içerdiği için bebeği enfeksiyonlardan korur. TNSA 2013'e göre ülkemizde, çocukların \%50'si doğumdan sonraki ilk bir saat içinde emzirilmeye başlanmaktadır (4).

Beşbenli ve arkadaşlarının yaptığı çalışmada tamamlayıcı besine geçişte annelerin \%42,2'si 4. aydan önce başladığını belirtirken, \%52,8'sinin 4-6 aylar arasında ve \%7'sinin 6. aydan sonra tamamlayıcı besinlere başladığı tespit edilmiştir (10). Türkiye'de yapılan çeşitli araştırmalarda ilk 4 ay sadece anne sütü ile beslenme oranları \%54 ile \%65 arasında, ortalama tamamlayıcı gıdaya başlama zamanları 3.5 ile 4.6 ay arasında, emzirme süreleri 6.2 ile 10.4 ay arasında değiştiği belirtilmektedir $(11,12,13,14)$. Ünalan ve arkadaşlarının yaptığı çalışmada ise annelerin \%58'i ek gıdaya 6. aydan önce başlamış ve 0-3 ayda başlama oranı \%33 olarak saptanmıştır (15). Bu çalışmada 0-6 aylık bebekleri olan annelerin \%71,6'sı ek gıda kullanmaktadır. Bodur ve arkadaşları tarafından yapılan araştırmada annelerin ek gıdaya 4. aydan önce başlama sıklığı genel olarak \%68 olarak bulunmuştur (16). Başka bir çalışmada ise annelerin \%25,3'üne 1-3 aylık iken, \%49,6'sına 4-6 aylık iken ek gıdaya başlanmıştır (6). Güneş ve arkadaşlarının yaptığı çalışmada ilk 6 ayda çocukların \%50'sine formül mama uygulanmasına başlandığı bildirilmiştir (17). Emzirme süresi uzun olmasına karşılık tamamlayıcı besinlere erken ya da çok geç başlanması Ülkemizde sorun oluşturmakta ve malnütrisyona yol açabilmektedir (4).

Eğitim seviyesi anne sütü verme süresini olumlu etkilediği gibi, olumsuz etkilediğini belirten çalışmalarda vardır $(18,19)$. Kanada'da yapılan çalışmada emzirme oranının \%21.2'den \%35'e artış göstermesinin yanında eğitimli annelerin daha kısa süre emzirdikleri belirtilmiştir (19). Hindistan'da yapılan 384 anne ile yapılan çalışmada ise annenin eğitim düzeyinin artmasının anne sütü verme süresini olumlu etkilediği görülmektedir (20). Amerika Birleşik Devletleri (ABD)'nde 4-6 ay emziren toplam 3515 anne 20002004 yılları arasında izlenmiş ve eğitim seviyesi artıkça, emzirme oranlarının arttığı gösterilmiştir (21). Bu çalışmada lise ve üstü eğitimli annelerin \%70 oranında daha uzun süre anne sütü verdikleri saptanmıştır. Bebeklere erken yaşta tamamlayıcı besinlerin verilmesi; bebek hastalıklarına ve ölümlerine yol açan nedenlerden biri olarak sindirim sistemi enfeksiyonları riskini artırması açısından oldukça önemlidir. TNSA-2013 verilerine göre 2 aylıktan küçük çocukların \%10'unun anne sütü ile beraber su, içinde su olan sıvılar ve meyve suyu aldıklarını göstermektedir. 6.aydan 16 . aya kadar bebeklerin yarısından fazlasına hem anne sütü hem de tamamlayıcı besin verilmiștir. 16. aydan sonra düşmeye başlamakta ve 24-27 aylık çocuklarda \%14'e düşmektedir. Çocuğun emzirilme süresi ve yoğunluğu kadar tamamlayıcı besin ve sıvı almaya başladığı yaş da çok önemlidir. Altı aydan küçük ve emzirilen çocuklar için 
\%28 ile formül mama en çok verilen tamamlayıcı besindir. Toplamda emzirilen ve emzirilmeyen 3 yaş altı çocuklara en çok verilen gıda tahıl ürünleridir (4). Araştırmamızda, ikinci 3 aylık dönemde yaklaşık iki anneden biri yoğurt yedirirken, muhallebi ve ev yapımı meyve püreleri en çok tercih edilen besinlerdir. Bitkisel ve hayvansal kaynaklı çok sayıda besin, tamamlayıcı beslenmede yer almaktadır. Çalışmamızda anne sütü verme süresi, tamamlayıcı gıda başlama zamanı ve emzirme süreleri TNSA 2013 verilerine göre olması gerekenin altındadır.

\section{Sonuç}

Emziren annenin beslenmesi hem annenin kendi sağlığı hem de bebek sağlığı açısından çok önemlidir. Annenin hamilelik ve emzirme döneminde optimum beslenmesi ile bebeğin sağlıklı doğumu ve anne sütü veriminin artmasına olumlu katkı sağlanmaktadır. Emzirme döneminde süt salgılanması nedeniyle anne normal ihtiyacından daha yüksek oranda enerji, protein, vitamin ve minerallere ihtiyaç duyar. Ülkemizde yapılan tüm çalışmalarda annelerde özellikle mikro besin eksikliğinin önemli bir sorun olduğu belirtilmektedir. Bu nedenle hem anne sağlığı için hem de ideal anne sütü içeriği ve bebek beslenmesi için annenin yeterli ve dengeli beslenmesi üzerinde durulması önceliğimiz olmalıdır $(7,8)$.

Araştırma bulgularımıza göre İlimizde emzirmeye başlama konusunda önemli bir sorun yoktur, ancak sürdürülmesi konusunda annelerin desteklenmesini sağlamak üzere II Sağlık Müdürlüğü ve Üniversite işbirliği ile anne sütünün farkındalığını artırıcı faaliyetlere intiyaç olduğu sonucuna ulaşılmıştır. Bu araştırmada; araştırma kapsamının düşük olması araştırmanın sınırlayıcı özelliğidir, ancak emziren anne ve $0-12$ ay bebek beslenmesi faaliyetlerinin İlimizde hangi düzeyde olduğunu göstermesi açısından oldukça önemlidir.

Ülkemizde anneler doğumdan itibaren bebeklerini anne sütü ile beslemeye başlamaktadır. Anne sütü ile yeterli ve doğru beslenme, bebeklerin motor-mental ve psikososyal gelişimlerini olumlu yönde etkiler. Bunun yanısıra anne sütü öncesi veya anne sütü ile birlikte diğer besinlerin gereksiz yere bebeğe verilmesi de önlenmelidir. Bu nedenle doğum öncesi ve sonrası annelerin sağlık personeli, medya kamu spotları, dergi, gazete ve internet yayınları ile anne sütü ve emzirme konusunda daha fazla bilgilendirilmeleri ve bilinçlendirilmeleri önem arz etmektedir. Anne sütünün özendirilmesi, tamamlayıcı gıdalar ve başlama zamanları, anne sütüne benzer bebek formülasyonları vb. bilgilendirmelerde yazılı ve görsel medya daha etkin yer alarak Sağlık Bakanlığı öncülüğünde annelerin 0-12 ay beslenmesi ve bebek beslenmesi konusunda bilinç ve güven duyguları artırılmalıdır.

Teşekkür: Bu çalışma 2015 yılında TÜBITAK- 2209/A Lisans Öğrencileri Araştırma Projeleri Destekleme Programı kapsamında TÜBITAK-BIDEB tarafından desteklenmiştir.

\section{Kaynaklar}

1. Anonymous, Infant and young child feding. http://www. who.int/topics/breastfeeding/en/ Erişim 11.03.2016

2. Anonymous, 10 facts on breastfeeding.http://www.who. int/features/factfiles/breastfeeding/en/ Erişim11.03.2016

3. Anonim, İlk altı ay sadece anne sütü.http://www.unicef. org/turkey/pc/_mc36.html Erişim 09.10.2015

4. Türkyılmaz A, Çavlin A. Çocukların ve annelerin beslenme durumu. Türkiye Nüfus ve Sağlık Araştırmaları. Ankara. Hacettepe Üniversitesi Nüfus Etütleri Enstitüsü Sağlık Bakanlığı, Kalkınma Bakanlığı. 2014. Yayın No: NEE-HÜ.14.01, 371s.

5. Akova S, Yazar A, Güven Ş, Aydoğdu S, Toklucu M, Tamer $C$. Anne sütü alan bebeklerin 0-36 ay arası büyüme ve gelişmelerinin değerlendirilmesi. Dicle Tıp Dergisi 2012; 39(4):542-546.

6. Açık Y, Dinç E, Benli S, Tokdemir M. Elazığ ilinde yaşayan 0-2 yaş grubu çocuğu olan kadınların bebek beslenmesi ve anne sütü konusundaki bilgi, tutum ve uygulamaları. Turkiye Klinikleri Journal of Pediatrics 1999; 8999; 8(2):53-62.

7. Samur G. Anne sütünün çoklu doymamış yağ asitleri bileşimi ile omega 6 /omega 3 yağ asitleri oranı. Beslenme ve Diyet Dergisi 2002;31:39-42.

8. Giray H. Anne sütü ile beslenme. Sted 2004;13(1):12-15. 9. Ünsür $E$, Gündoğan $B$, Ünsür $M$, Okan F. Emziren annelerin emzirme ile ilgili bilgi ve tutumlarının değerlendirilmesi. Eurasian Journal of Family Medicine 2014;3(1):33-40.

10. Beşbenli K, Avgen B, İncioğlu A, Çetinkaya F. İstanbul'da üç farklı sosyoekonomik grupta yer alan annelerin emzirme ve bebek beslenmesi konusundaki bilgi ve davranışları. Çocuk Sağlığı ve Hastalıkları Dergisi 2013;56:76-81.

11. Şahin S. Süt çocuğu beslenmesinde ailelerin tutumları, gerisindeki sosyal faktörler ve sonuçlarının irdelenmesi. Ok Meydanı Tıp Dergisi 2003;20(2):34-37.

12. Yiğit EK, Tezcan S. Bebeklerin beslenme alışkanlıkları, çocukların ve annelerin beslenme durumu. Hacettepe Üniversitesi Nüfus Etütleri Enstitüsü, Ankara.2004:141-155. 13. Yiğit EK, Tezcan S. Bebeklerin beslenme alışkanlıkları, çocukların ve annelerin beslenme durumu. Türkiye Nüfus ve Sağlık Araştırması, Hacettepe Üniversitesi Nüfus Etütleri Enstitüsü, Ankara, 2003: 141-146.

14. Alikaşifoğlu M, Erginöz E, Taşdelen GE. Bir üniversite 
hastanesine devam eden annelerde tek başına anne sütü verme süresine etki eden faktörler: Türk Pediatri Arşivi 2000; 35(3): 148-155.

15. Ünalan P, Akgün T, Çiftçili $S$, Boler İ, Akman M. Why do mother attending a baby-friendly mother and child health care unit start early solid food to their babies. Turk Pediatri Arşivi 2008; 43: 59-64.

16. Bodur S, Yıldız H, Mermer M, Oran B. Konya il merkezinde annenin çalışma durumuna göre emzirme süresi ve ek gıda ile ilgili tutumu. Selçuk Üniversitesi Tıp Fakültesi Dergisi 2002;18:97-101.

17. Güneş M, Atay G, Şimşek F, Uluyol B, Suskan E, Gülnar S. Anne sütünün yetersiz alımına neden olan faktörler. 47. Milli Pediatri Kongresi, 3. Milli Çocuk Hemşireliği Kongresi Özet Kitabı, İstanbul 2003;21-23.

18. Bai DL, Fong DY, Tarrant M. Factors Associated with breastfeeding duration and exclusivity in mothers returning to paid employment postpartum. Matern Child Health $\mathrm{J}$ 2015;19(5):990-999.

19. Newby RM, Davies PS. A prospective study of the introduction of complementary foods in contemporary Australian infants: What, when and why? J Paediatr Child Health 2015;51(2):186-191.

20. Bagul AS, Supare MS. The infant feeding practices in an urban slum of Nagpur, İndia. J Journal of Clinical and Diagnostic Research 2012; 6(9):1525-7.

21. Chin AC, Myers L, Magnus JH. Race, education and breastfeeding initiation in Louisiana, 2000-2004. Journal of Human Lactation 2008;24(2):175-85. 